\title{
GASEOUS COMPONENTS IN THE ATMOSPHERE AND THE HISTORIC RECORD REVEALED BY ICE CORES
}

\author{
by
}

\author{
B. Stauffer and H. Oeschger
}

(Physikalisches Institut, Universität Bern, Sidlerstrasse 5, CH-3012 Bern, Switzerland)

\begin{abstract}
The composition of air in bubbles of ice reveals important information on the composition of the atmosphere at the time at which the ice was formed. The enclosed air has essentially an atmospheric composition if the ice formation occurred by dry sintering of snow and firn at low temperatures. The history of atmospheric $\mathrm{CO}_{2}$ concentration is of special interest due to its present increase and its climatic implications. Currently, $\mathrm{CO}_{2}$ analysis of air extracted from ice cores seems the best and most direct method of determining the natural $\mathrm{CO}_{2}$ concentration before 1950 and possible pre-industrial variations. Analyses of ice samples representing the past $40 \mathrm{ka}$ show that there were significant changes in concentration of atmospheric $\mathrm{CO}_{2}$ at the end, and probably during part, of the last glaciation. $8^{13} \mathrm{C}$ measurements on $\mathrm{CO}_{2}$ extracted from ice cores can indicate possible mechanisms causing these changes in the concentration of atmospheric $\mathrm{CO}_{2}$.
\end{abstract}

\section{INTRODUCTION}

Precipitations that fell $>100 \mathrm{ka}$ ago are preserved in a complete and well-stratified order in the central parts of the large polar ice sheets. Each precipitation event carries information concerning environmental and climatic conditions at the time that it fell and was exposed at the surface. The snow undergoes a metamorphosis from snow to firn, and finally to ice, and during the transition from firn to ice, atmospheric air is enclosed in bubbles. The air which is trapped in the bubbles at the time of ice formation remains at low temperatures as the years pass by. Information on the atmospheric composition obtained by analyzing air extracted from bubbles can be compared with climatic parameters obtained by analyzing the surrounding ice. However, one has to consider that the air is younger than the ice, since the transition from firn to ice occurs from 50 to 3000 a after deposition of the snow (Schwander and Stauffer 1984).

Scientists became interested in the composition of air in bubbles of glacier ice in the last century (Hamberg 1895). Scholander and collaborators (Coachman and others 1956, Scholander and others 1956) made the first comprehensive investigation and invented new methods to extract and analyze air from ice samples. The extraction techniques and analytical methods have been further improved and new analytical techniques are now applied. Most important for the progress of ice-core analysis is, however, the availability of suitable ice samples obtained by core drilling in the central parts of ice sheets.

We used, in our laboratory, samples which were obtained mainly from the deep ice cores from Camp Century, Greenland and Byrd station, Antarctica drilled by Lyle Hansen (Ueda and Garfield 1969) and from Dye 3, Greenland drilled in the course of the Greenland Ice Sheet Program (Gundestrup and others 1984). Important results were obtained with samples from intermediate ice cores from South Pole and Siple stations, Antarctica drilled by the Polar Ice Coring Office, Nebraska Coordinates, mean annual air temperature and annual accumulation at all these locations are given in Table I.
In our laboratory, gases are extracted using dry extraction systems in which bubbles are opened mechanically at low temperature to release the gas. $\mathrm{CO}_{2}$ analysis is carried out on ice samples of about $2 \mathrm{~g}$ size using a crusher combined with an infrared laser absorption spectrometer (Zumbrunn and others 1982). A new extraction system permits the extraction of gas from samples of up to $800 \mathrm{~g}$ (Moor and Stauffer 1984). This amount of extracted gas allows us to measure isotope ratios on the separated $\mathrm{CO}_{2}$ and trace gases.

\section{ICE AS A SAMPLING AND STORAGE DEVICE}

When ice is formed by sintering of dry firn, the pore volume becomes separated in isolated bubbles with no further interaction with the atmosphere at the firn/ice transition. The analysis of the $\mathrm{N}_{2} / \mathrm{O}_{2} / \mathrm{Ar}$ ratios in air which was extracted from ice samples originating from cold areas without summer melting shows that, within the limits of error, these ratios agree with those found in the atmosphere. This indicates that the trapping of air in ice is essentially a physical process without leading to differentiation of the gas components. However, other components such as $\mathrm{CO}_{2}$ have specific physico-chemical properties, e.g. a high solubility in water. We expect no deviation of the $\mathrm{CO}_{2}$ concentration in bubbles of ice sintered from dry firn if both adsorption of air components on the firn grain surfaces and air enclosed during snowflake formation can be neglected.

Klinger and Ocampo (1979) measured the adsorption of $\mathrm{CO}_{2}$ on ice, and, according to their results, the amount of $\mathrm{CO}_{2}$ adsorbed on firn grains can be neglected. We have measured the $\mathrm{CO}_{2}$ concentration of air extracted from firn of $35 \mathrm{~m}$ depth at the South Pole (Stauffer and others 1981). The measured $\mathrm{CO}_{2}$ concentration at this depth agrees within the limits of error with the present atmospheric $\mathrm{CO}_{2}$ concentration. From these two results we conclude that adsorption effects can be neglected and that air in the open pore space in firn has atmospheric composition.

Measurements on snow and firn samples from North Central station, Greenland show that there is air occluded in firn grains, which is enriched in $\mathrm{CO}_{2}$ (Stauffer and others 1981). The amount of this air decreases with depth, probably due to a kind of zone refining process paralleling crystal growth. It was mentioned earlier that a small amount of $\mathrm{CO}_{2}$ remaining in the firn grains could lead to a small but significant increase of the $\mathrm{CO}_{2}$ concentration in air extracted from ice samples (Stauffer and others 1984). The diameter of firn grains grows by a factor of from 2 to 10 from the surface to bubble close-off depth, depending on temperature and accumulation rate. The grain volume increases therefore by a factor of from 8 to 1000 . If we assume that the $\mathrm{CO}_{2}$ content is $80 \mu \mathrm{l} \mathrm{kg}-1$ in the original nucleus of the firn grain as observed in young firn, and zero in the part accumulated by crystal growth, the $\mathrm{CO}_{2}$ content at the firn-ice transition will be less than in young firn by a factor of from 8 to 1000 . This 0.08 to $10 \mu 1 \mathrm{~kg}^{-1}$ corresponds to an increase in the measured $\mathrm{CO}_{2}$ concentration of about 0.8 to 100 ppmv; for polar regions without summer melting it is probably less than 25 ppmv. 
TABLE I. CHARACTERISTICS OF DRILL SITES ON THE ANTARCTIC AND GREENLAND ICE SHEETS (Schwander and Stauffer 1984)

\begin{tabular}{|c|c|c|c|c|c|c|}
\hline Site & Locatic & (long) & $\begin{array}{l}\text { Mean } \\
\text { annual air } \\
\text { temperature } \\
\left({ }^{\circ} \mathrm{C}\right)\end{array}$ & $\begin{array}{l}\text { Annual } \\
\text { accumu- } \\
\text { lation } \\
\text { water } \\
\text { equivalent } \\
\text { (m) }\end{array}$ & $\begin{array}{l}\text { Width of age } \\
\text { distribution } \\
\text { (a) }\end{array}$ & $\begin{array}{l}\text { Difference between } \\
\text { age of ice and } \\
\text { mean age of air } \\
\text { (a) }\end{array}$ \\
\hline $\begin{array}{l}\text { Measured at: } \\
\text { Siple station }\end{array}$ & $75^{\circ} 55^{\prime} \mathrm{s}$ & $83^{\circ} 55^{\prime} \mathrm{W}$ & -24 & 0.5 & 22 & 95 \\
\hline \multicolumn{7}{|l|}{ Calculated for } \\
\hline Vostok & $78^{\circ} 28^{\prime} \mathrm{S}$ & $106^{\circ} 48^{\prime} \mathrm{E}$ & -57 & 0.022 & 590 & 2800 \\
\hline Dome C & $74^{\circ} 39^{\prime} \mathrm{s}$ & $124^{\circ} 10^{\prime} \mathrm{E}$ & -53 & 0.036 & 370 & 1700 \\
\hline $\begin{array}{l}\text { South Pole } \\
\text { station }\end{array}$ & $90^{\circ} 00^{\prime} \mathrm{s}$ & & -51 & 0.084 & 220 & 950 \\
\hline Byrd station & $79^{\circ} 59^{\prime} \mathrm{S}$ & $120^{\circ} 01^{\prime} \mathrm{W}$ & -28 & 0.16 & 54 & 240 \\
\hline $\begin{array}{l}\text { North } \\
\text { Central }\end{array}$ & $74^{\circ} 37^{\prime} \mathrm{N}$ & $39^{\circ} 36^{\prime} \mathrm{W}$ & -31.7 & 0.11 & 76 & 350 \\
\hline Crête & $71^{\circ} 07^{\prime} \mathrm{N}$ & $37^{\circ} 19^{\prime} \mathrm{W}$ & -30 & 0.265 & 46 & 200 \\
\hline $\begin{array}{l}\text { Camp } \\
\text { Century }\end{array}$ & $77^{\circ} 11^{\prime} \mathrm{N}$ & $61^{\circ} 09^{\prime} \mathrm{W}$ & -24 & 0.34 & 31 & 130 \\
\hline Dye 3 & $65^{\circ} 11^{\prime} \mathrm{N}$ & $43^{\circ} 50^{\prime} \mathrm{W}$ & -19.6 & 0.5 & 22 & 90 \\
\hline
\end{tabular}

The $\mathrm{CO}_{2}$ concentration in bubbles may be affected, after enclosure, by interactions with the ice itself and with occluded impurities during the long storage times involved.

After isolation from the atmosphere, bubbles shrink due to the hydrostatic pressure of the surrounding ice. Below a certain depth the bubble size decreases faster than would be expected due to the increasing pressure alone. This is because gases start to diffuse into the ice and to be trapped as air hydrates (Miller 1969, Shoji and Langway 1982). After decompression of the ice cores at the surface, air bubbles start to form again. To investigate a possible enrichment or depletion of $\mathrm{CO}_{2}$ in the air of reformed bubbles, we analyzed samples, using the same ice core from Dye 3, from $1615 \mathrm{~m}$ below the surface at times of one week, two months and one year after recovery (Neftel and others 1983). Within the limit of experimental error, the same $\mathrm{CO}_{2}$ concentrations were measured. Based on measurements on the same ice samples, the permeability of ice at $-20^{\circ} \mathrm{C}$ for $\mathrm{CO}_{2}$ was estimated to be about $3 \times 10^{-24} \mathrm{~m}^{2} \mathrm{~s}^{-1} \mathrm{~Pa}^{-1}$. The small permeability (of the same order as the permeability of $\mathrm{N}_{2}$ through iron at $150^{\circ} \mathrm{C}$ ) excludes the possibility of a loss of $\mathrm{CO}_{2}$ during storage of ice cores, provided the ice is not fractured.

The question of whether $\mathrm{CO}_{2}$ in bubbles or in the form of air hydrates in the ice may react with impurities in the ice is of special interest, since changes in $\mathrm{CO}_{2}$ occasionally parallel changes in the dust concentration of ice (Stauffer and others 1981, W Dansgaard personal communication). Concerning the observed transition from low to high $\mathrm{CO}_{2}$ concentrations at the end of the last glaciation, which will be discussed in section 4 , the increase of the $\mathrm{CO}_{2}$ concentration parallels a decrease of the dust content in all the measured ice cores. We measured the $\mathrm{pH}$ value of melted samples from Camp Century and Byrd station after $\mathrm{CO}_{2}$ was extracted (Stauffer and others 1981). The $\mathrm{pH}$ value of all samples measured from Camp Century is
$>7$ (since it was measured after gas extraction this does not indicate that the ice is alkaline) and is higher for samples from the last glaciation. The samples showing the lowest $\mathrm{CO}_{2}$ contents have the highest $\mathrm{pH}$ values. All samples from Byrd station, on the other hand, show $\mathrm{pH}$ values $<7.2$. They show the same trend concerning $\mathrm{CO}_{2}$ at the end of the last glaciation as the samples from Camp Century and the total change is of the same magnitude. The increase of the $\mathrm{CO}_{2}$ concentration in the ice cores from Dome C (Barnola unpublished) and Byrd station occur significantly above the dust increase in the same ice core. We conclude therefore that in this case the change of the $\mathrm{CO}_{2}$ content is most probably caused by a change of the atmospheric $\mathrm{CO}_{2}$ concentration. An interaction of $\mathrm{CO}_{2}$ with impurities in ice cannot be completely excluded and variations of the $\mathrm{CO}_{2}$ concentration in a certain time interval should be observed in at least two ice cores with different concentrations of impurities before they can be attributed unequivocally to an atmospheric $\mathrm{CO}_{2}$ concentration change.

\section{SOME RESULTS FROM ICE-CORE ANALYSIS}

The main components of air: $\mathrm{N}_{2}(78.08 \%), \mathrm{O}_{2}$ $(20.95 \%)$, Ar $(0.93 \%)$, and most of the noble gases, are considered to be permanent and their variations during the last $100 \mathrm{ka}$ are expected to be extremely small. Except for water vapour, the first variable gases which attracted general attention were $\mathrm{CO}_{2}$ and ozone (Junge 1963). Both are important for life and for the radiation balance. Other components present in smaller concentrations and varying, because of differences in natural sources or sinks, or increasing, because of anthropogenic impacts, have attracted attention in recent years. $\mathrm{CH}_{4}, \mathrm{~N}_{2} \mathrm{O}, \mathrm{CO}$ and halocarbons are among the more important.

Scholander and others (1956) reported an $\mathrm{O}_{2}$ concentration in air extracted from two icebergs which was 0.6 to $0.85 \%$ lower than that in the atmosphere. It 
was estimated that the icebergs originated from the central part of Greenland and were very old. They speculated that the atmospheric $\mathrm{O}_{2}$ concentration could have been lower during the beginning of the Pleistocene, owing to reduced photosynthesis.

In air extracted from ice samples from Camp Century, Raynaud and Delmas (1977) found a mean $\mathrm{O}_{2}$ concentration of $20.87 \%$ for samples of Holocene age and $20.69 \%$ for samples from the Wisconsin period. They attribute this small but significant difference either to a lower atmospheric $\mathrm{O}_{2}$ concentration during the Wisconsin or to a change of the adsorption behaviour of $\mathrm{O}_{2}$ on the surface of firn grains due to different firn temperatures.

Variations of the atmospheric $\mathrm{O}_{2}$ concentration, due to changes in the activity of photosynthesis and oxidation, are expected to be of the order of $0.01 \%$ or less. Precise and reliable measurements of the atmospheric $\mathrm{O}_{2}$ concentration in the past, based on ice-core analysis, could give an important insight into changes of biological activity and oxidation of organic material. The ratio of the stable isotopes ${ }^{18} \mathrm{O} /{ }^{16} \mathrm{O}$ may also have varied in the past (e.g. during the last glaciation), because of an indirect interaction with the oxygen in ocean water (Bender personal communication).

Ozone, which is a very reactive gas, might be expected to react with impurities in the firn and in the ice and is therefore probably not suitable for investigation by ice-core analysis.

Most investigations concern the atmospheric $\mathrm{CO}_{2}$ concentration. The results will be discussed separately in the next section.

The pre-industrial atmospheric concentration of most of the trace gases is not well known or not known at all. Ice-core analyses will help to determine the pre-industrial concentrations of some trace gases as well as the time history of a possible increase. Attempts to measure $\mathrm{CH}_{4}, \mathrm{~N}_{2} \mathrm{O}, \mathrm{CO}$ and halocarbons have been made in different laboratories. Craig and Chou (1982) reported interesting results concerning $\mathrm{CH}_{4}$. Based on measurements carried out on ice-core samples from Dye 3 they conclude that the atmospheric $\mathrm{CH}_{4}$ concentration was about 0.7 ppmv during the last $20 \mathrm{ka}$ until about AD 1600. From this time, the $\mathrm{CH}_{4}$ concentration started to increase linearly, reaching a concentration of about $1.1 \mathrm{ppmv}$ in 1920. There was a faster increase afterwards, the present (1980) value of the atmospheric $\mathrm{CH}_{4}$ concentration being about 1.7 ppmv.

We are now measuring the $\mathrm{CH}_{4}$ concentration in ice cores from South Pole and Siple stations. First preliminary measurements of air extracted with a vacuum melt extraction system confirm the results of Craig and Chou. After the success of the dry extraction system concerning $\mathrm{CO}_{2}$, we would like to analyse air extracted with this system. However, up to now dry extraction is causing higher and more variable blank values than vacuum melt extraction.

Of special interest are radioactive isotopes in the gas enclosed in bubbles. The best known is ${ }^{14} \mathrm{C}$. Results from ${ }^{14} \mathrm{C}$ measurements on $\mathrm{CO}_{2}$ extracted from ice samples will be discussed below. Very important for dating purposes are radioactive isotopes of noble gases, since they are not affected by geochemical variations. ${ }^{39} \mathrm{Ar} \quad\left(\mathrm{T}_{1 / 2}=269\right.$ a) measurements have been used for dating ice at different depths (Loosli 1983). ${ }^{85} \mathrm{Kr}\left(\mathrm{T}_{1 / 2}=\right.$ 10.7 a) will be used to check if air in the open pore space of firn is well-mixed down to the transition zone from firn to ice. ${ }^{81} \mathrm{Kr}\left(\mathrm{T}_{1 / 2}=2 \times 10^{5}\right.$ a) will be an ideal isotope for dating very old ice, as soon as progress in the analytical technique allows the use of small ice samples (Kramer and others 1984).

\section{RESULTS CONCERNING $\mathrm{CO}_{2}$ AND THE RATIOS OF CARBON ISOTOPES}

\subsection{Pre-industrial atmospheric $\mathrm{CO}_{2}$ concentration}

The $\mathrm{CO}_{2}$ concentration in air bubbles of very cold ice is essentially atmospheric. Small deviations cannot be excluded, e.g. those due to microbubbles. Extraction and analytical methods have to be tested step by step, and absolute calibration of the procedure has not yet been possible, since ice formed during a period with known atmospheric $\mathrm{CO}_{2}$ concentration is not available. Two laboratories at Bern and Grenoble have compared two different procedures by performing an inter-laboratory calibration, measuring samples from the same ice core (Barnola and others 1983). The results of measurements on sections of ice cores drilled at Dome C (East Antarctica) and Byrd station (West Antarctica) did agree within the error limits of about $3 \%$ ( 9 ppmv absolute). The mean $\mathrm{CO}_{2}$ concentration of the extracted air was found to be $258 \mathrm{ppmv}$. Using the same procedures, ice samples from six different locations in Antarctica and Greenland were measured, covering a time interval from

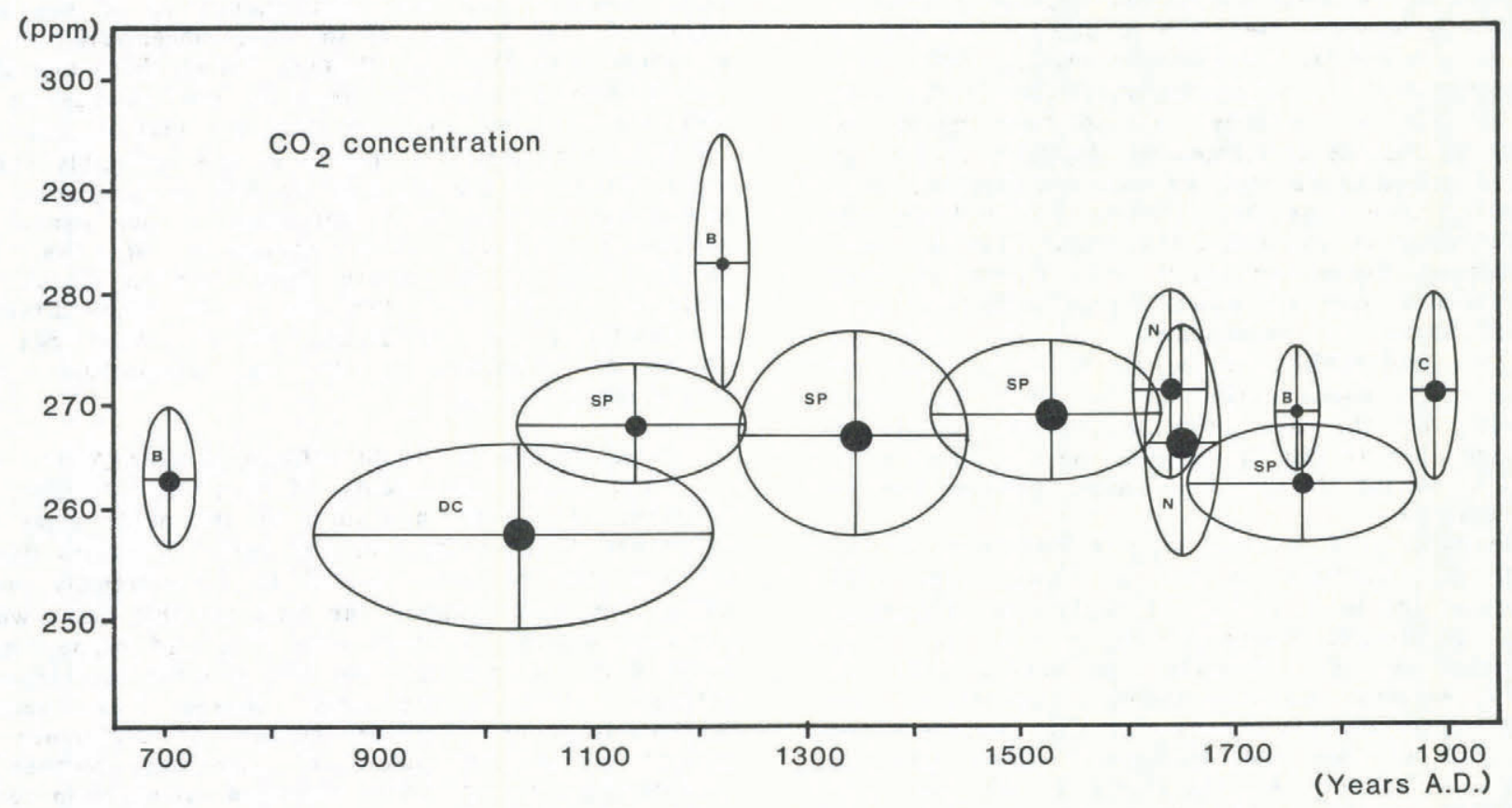

Fig.1. $\mathrm{CO}_{2}$ concentration of air extracted from $2 \mathrm{~g}$ ice samples and measured with an infrared laser absorption spectrometer. Ice samples are from Dome C (DC), South Pole station (SP) Byrd station (B), North Central (N) and Crête (C). Large dots indicate mean values of more than 30 measurements, medium dots of 8 to 30 , and small dots less than 8 . 


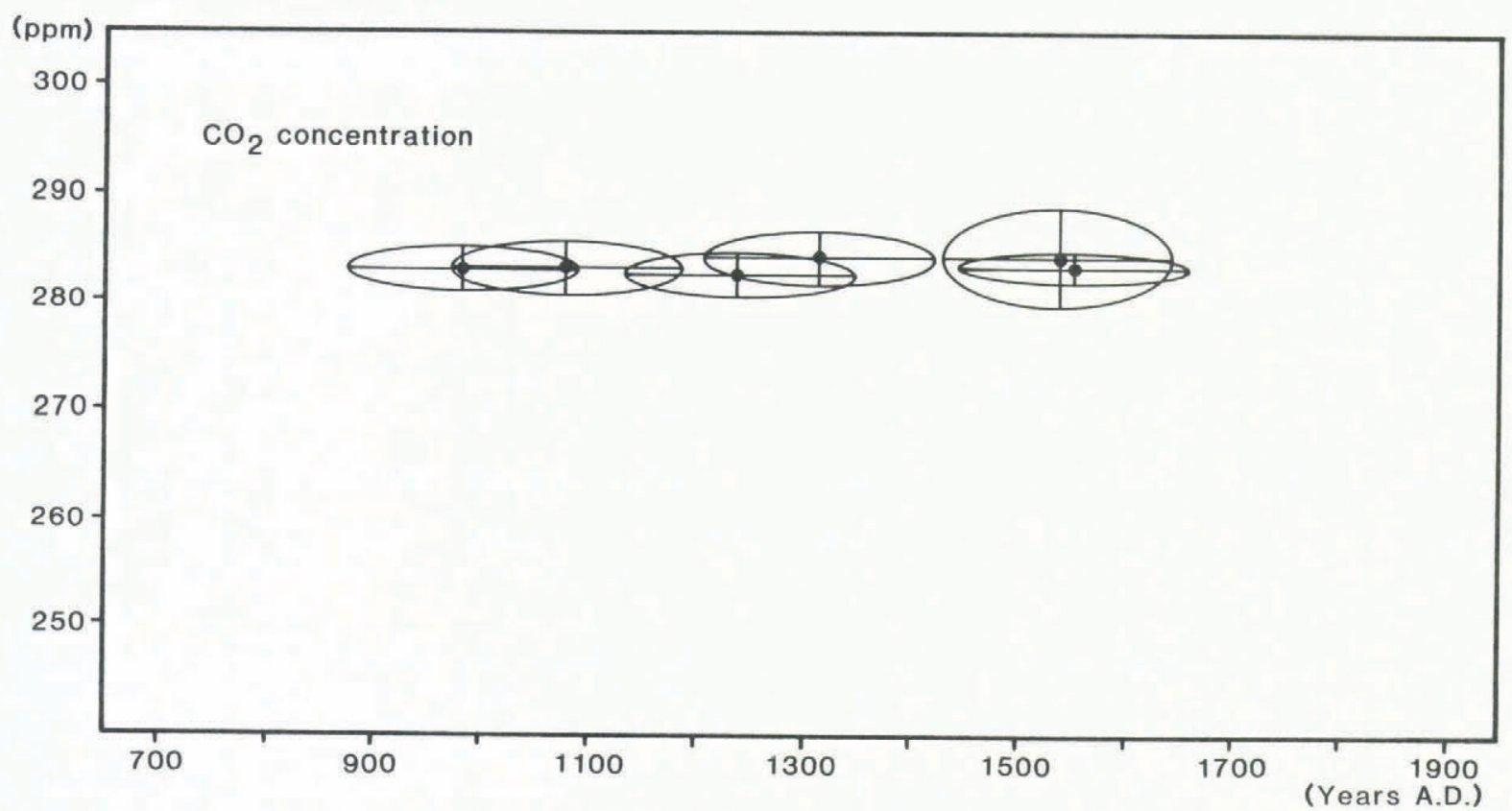

Fig.2. $\mathrm{CO}_{2}$ concentration of air extracted from $550 \mathrm{~g}$ ice samples from South Pole station,

$2500 \mathrm{BP}$ to about $\mathrm{AD}$ 1850. The results for the mean concentrations occurring at all these locations are in the range of 258 to 270 ppmv. Results from measurements made in Bern are shown in Figure 1.

A new extraction system for much larger ice samples $(500 \mathrm{~g})$ was developed in our laboratory at Bern after the inter-laboratory comparison. Measurements of the $\mathrm{CO}_{2}$ concentration on gases extracted with the new device from samples from South Pole station gave a mean value of $283 \pm 2$ ppmv (Fig.2). With the system used for the inter-laboratory comparison we found $267 \pm 6$ ppmv. With the old system, gas released during dry extraction expands into an absorption cell of an infrared laser absorption spectrometer (Zumbrunn and others 1982) where the $\mathrm{CO}_{2}$ concentration is measured whereas with the new system all extracted gas is collected by condensation at $15 \mathrm{~K}$. Searching for the cause of the discrepancy between the two extraction methods, we observed a small depletion of $\mathrm{CO}_{2}$ in that fraction of the gas which expands into the absorption cell. The gas has to pass a cold trap where water vapour is transporting $\mathrm{CO}_{2}$ preferentially, which can lead to a demixing of air by a flux of water vapour. According to recent measurements made in our laboratory, we would have to correct our earlier results to give values about 15 ppmv higher. Tests in the laboratory in Grenoble, however, do not seem to justify a correction of their earlier results (D Raynaud personal communication). Further comparisons with the laboratory in Grenoble are planned. The uncertainty concerns only the absolute values; we have great confidence in results showing variations, especially if they are measured on the same core. Recent measurements in Grenoble and in Bern have also shown that there are variations of the pre-industrial atmospheric $\mathrm{CO}_{2}$ concentration in the range of 10 ppmv. Comparisons have therefore to be done for the same time interval.

Neighbouring air bubbles in an ice sample may have different ages, since one bubble may have been isolated at the beginning and an adjacent one at the end of the enclosure process. The time resolution, i.e. the width of the age distribution of the enclosed air, is determined by the duration of the gas enclosure process which depends on firn temperature and annual accumulation rate (Schwander and Stauffer 1984) (Table I). Samples from locations with high annual accumulations are best suited to yield good time resolutions which are necessary to investigate, for example, the anthropogenic increase of the atmospheric $\mathrm{CO}_{2}$ concentration. From the first measurements of samples from Siple station (West Antarctica) we estimate that the history of the $\mathrm{CO}_{2}$ increase during the last 150 a can be reconstructed with a time resolution of about 20 a and that the results will be overlapping or adjacent to results from direct measurements on Mauna Loa started in 1958. The results are, however, preliminary and it is too early to report on them in this paper. 4.2. Large variations at the end of and during the
last glaciation

There is evidence from different ice cores that the atmospheric $\mathrm{CO}_{2}$ concentration was lower by 70 to 100 ppmv during the last glaciation than in the pre-industrial period of the Holocene (Oeschger and Stauffer in press, Barnola unpublished). We will discuss the chronology of the increase at the end of the last glaciation and the possibility of large variations of atmospheric $\mathrm{CO}_{2}$ concentration during glaciation as reported by Stauffer and others (1984, 1985) (Fig.3).
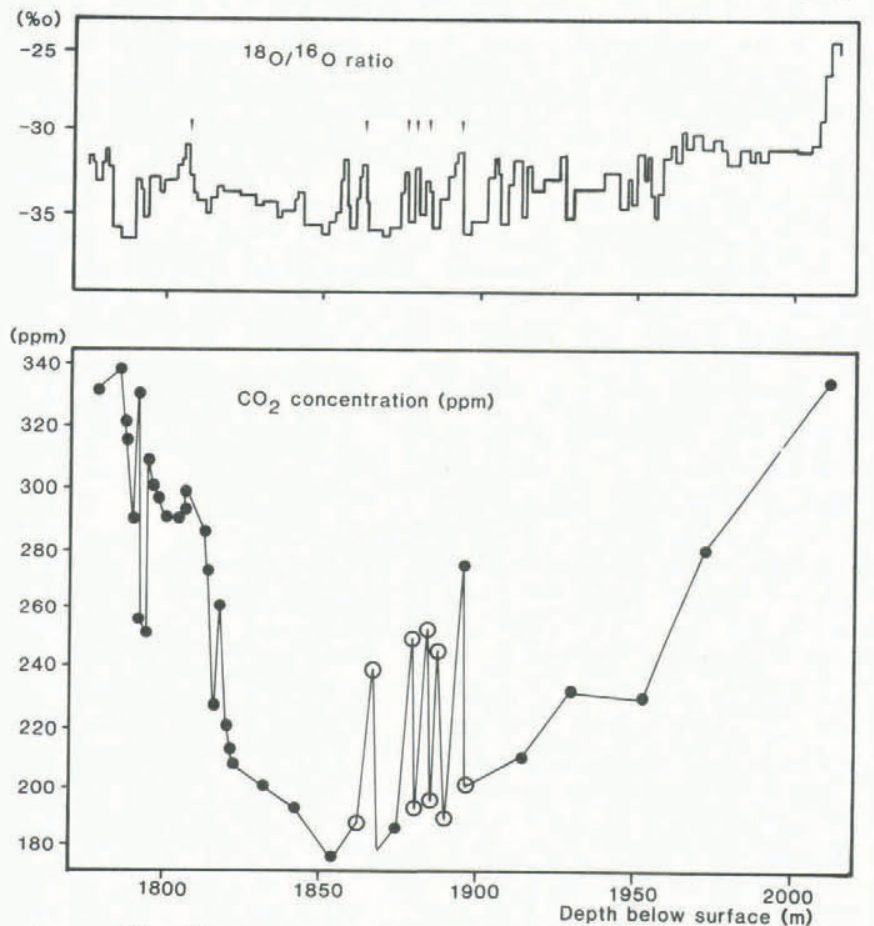

Fig.3. ${ }^{18} \mathrm{O} /{ }^{16} \mathrm{O}$ ratio and $\mathrm{CO}_{2}$ concentration measured on the deep ice core from Dye $3 \cdot{ }^{18} \mathrm{O} /{ }^{16} \mathrm{O}$ results according to Dansgaard and others (1982), $\mathrm{CO}_{2}$ results indicated by dots according to Stauffer and others (1985) and by circles according to Stauffer and others (1984). 
TABLE II. ${ }^{14} \mathrm{C}$ AGE OF TWO ICE SAMPLES FROM DYE 3 (Andrée and others 1984). THE CORRECTION OF THE ${ }^{14} \mathrm{C}$ AGES TAKES INTO ACCOUNT ${ }^{13} \mathrm{C}$ CORRECTIONS AND ${ }^{14} \mathrm{C}$ PRODUCTION VARIATIONS

\begin{tabular}{cccccccc}
$\begin{array}{l}\text { Mean } \\
\text { depth }\end{array}$ & $\begin{array}{c}\text { Amount } \\
\text { of ice }\end{array}$ & $\begin{array}{c}\text { Amount } \\
\text { of } \mathrm{CO}_{2}\end{array}$ & $\begin{array}{c}{ }^{14} \mathrm{C} \text { age } \\
\text { uncorrected }\end{array}$ & $\begin{array}{c}{ }^{14} \mathrm{C} \text { age corrected } \\
\text { air }\end{array}$ & ice & $\begin{array}{c}\text { Age determined by } \\
\text { seasonal } \\
\text { variations }\end{array}$ & $\begin{array}{c}\text { ice-flow } \\
\text { model }\end{array}$ \\
$(\mathrm{m})$ & $(\mathrm{kg})$ & $\left(\mathrm{cm}^{3}(\mathrm{STP})\right)$ & (a) & (a) & (a) & (a) & (a) \\
1668 & 10.2 & 0.24 & $6420 \mp 650$ & $7550 \mp 660$ & $7640 \mp 660$ & $8304 \mp 50$ & 8132 \\
1732 & 11.2 & 0.28 & $7930 \mp 660$ & $9025 \mp 660$ & $9115 \mp 660$ & $9019 \mp 50$ & 9362 \\
\hline
\end{tabular}

There are two main questions concerning the increase at the end of glaciation: how fast was the increase, and did the $\mathrm{CO}_{2}$ increase occur before or after the climatic shift indicated by increasing $6^{18} \mathrm{O}$ values?

The possibility of a rapid increase around $13 \mathrm{ka}$ BP has been reported, based on measurements of samples from an ice core drilled at Dye 3 during the Greenland Ice Sheet Program (Stauffer and others 1985). This ice core has a good time resolution at the depth where the transition from Wisconsin to Holocene is observed, and is of excellent quality. At Dye 3 the mean annual air temperature at present is $-20^{\circ} \mathrm{C}$, and summer melting occurs regularly. We considered the possibility of this apparently rapid $\mathrm{CO}_{2}$ increase at the glacial/post-glacial transition being caused by the influence of meltwater leading to elevated $\mathrm{CO}_{2}$ concentrations in ice as unlikely, based mainly on $\delta^{18} \mathrm{O}$ measurements. Possibly we have underestimated the influence of the larger solar insolation during summer at the end of the last glaciation. Blatter and others (1984) calculated for the summer season at $60^{\circ} \mathrm{N}$ and $10 \mathrm{ka}$ BP a solar insolation for a clear sky of $22.04 \mathrm{MJ} \mathrm{m}^{-2} \mathrm{~d}^{-1}$, compared to the present value of $20.67 \mathrm{MJ} \mathrm{m} \mathrm{m}^{-2} \mathrm{~d}^{-1}$. This indicates that the summer temperature compared to the mean annual temperature was higher than at present. The formation of meltwater in summer cannot, therefore, be excluded in spite of low $\delta^{18} \mathrm{O}$ values. There could be an increasing influence of meltwater due to the climatic warming indicated by increasing $\delta^{18} \mathrm{O}$ values observed in the Dye 3 ice core at $1810 \mathrm{~m}$ depth.

New measurements on ice samples from Byrd station do not provide further evidence for a very rapid atmospheric $\mathrm{CO}_{2}$ increase, but do not disprove it either, as samples from the most important core section are no longer available. Results from ice samples from Dome C indicate that the increase occurred in two steps. The $\mathrm{CO}_{2}$ concentration increased, according to Barnola (unpublished), from 200 to $230 \mathrm{ppmv}$ about $16 \mathrm{ka} \mathrm{BP}$, and from $230 \mathrm{ppmv}$ to a value above the pre-industrial concentration about $11 \mathrm{ka}$ BP. The second increase occurred probably very rapidly.

In order to investigate the detailed chronology of the $\mathrm{CO}_{2}$ increase, an ice core from a very cold location with a good time resolution (high accumulation) and good quality is needed. The question of a possible time lag between increase of $\mathrm{CO}_{2}$ and climatic change is related to this chronology, and cannot be answered yet. An ice core drilled in central Greenland would be well suited to solve these problems.

The question arises if meltwater could be responsible for the elevation of $\mathrm{CO}_{2}$ values during short periods of warmer climate, as observed on ice samples from Dye 3 representing a period from about 30 to 40 ka BP (Stauffer and others 1984) (Fig.3). The solar insolation calculated by Blatter and others (1984) for the summer season is $20.99 \mathrm{MJ} \mathrm{m}^{-2} \mathrm{~d}^{-1}$ for $40 \mathrm{ka} \mathrm{BP}$, and $20.38 \mathrm{MJ} \mathrm{m}^{-2} \mathrm{~d}^{-1}$ for $30 \mathrm{ka}$ BP. The insolation was slightly higher than it is today but lower than it was at the end of the glaciation. Traces of meltwater in periods of relatively warm climate indicated by higher $\delta^{18} \mathrm{O}$ values cannot be excluded, but only a meltwater formation of the same order as exists today would cause the large increase observed. We still consider that the influence of meltwater is unlikely to be great.

The question of whether the rapid changes of the $\mathrm{CO}_{2}$ content are due to changes of atmospheric $\mathrm{CO}_{2}$ concentration has to be answered by analyses of ice-core samples from other locations. We measured samples from Byrd station from a small section where elevated $\mathrm{CO}_{2}$ values were expected based on $\delta^{18} \mathrm{O}$ measurements. No such elevated values were found, but this could be due to an error in the estimated age of the core section. A more complete survey of the Byrd core will be done within the next six months.

4.3. First ${ }^{13} \mathrm{C} /{ }^{12} \mathrm{C}$ results

The stable isotope ratio of $\mathrm{CO}_{2}\left({ }^{13} \mathrm{C} /{ }^{12} \mathrm{C}\right)$ extracted from ice samples provides a clue in the investigation of possible reasons for atmospheric $\mathrm{CO}_{2}$ concentration changes. $\mathrm{CO}_{2}$ produced from living biomass as well as from fossil fuels has a significantly lower $\delta^{13} \mathrm{C}$ than atmospheric $\mathrm{CO}_{2}$; on the other hand, $\mathrm{CO}_{2}$ variations due, for example, to temperature changes in the ocean would not significantly influence $\delta^{13} \mathrm{C}$.

The ${ }^{13} \mathrm{C} /{ }^{12} \mathrm{C}$ and ${ }^{18} \mathrm{O} /{ }^{16} \mathrm{O}$ ratios of $\mathrm{CO}_{2}$ extracted from ice samples from South Pole and from Byrd station have been measured (Friedli and others 1984). Air is extracted from samples of about $500 \mathrm{~g}$ by dry extraction (Moor and Stauffer 1984). The $\mathrm{CO}_{2}$ is separated from the air by condensation at the temperature of liquid nitrogen. The $\delta^{13} \mathrm{C}$ and $\delta^{18} \mathrm{O}$ values of the $\mathrm{CO}_{2}$ samples, of typically $15 \mu \mathrm{l}$ STP volume, are measured in a MAT 250 triple collector mass spectrometer. The overall precision, including extraction, separation and analysis, is estimated to be $0.22^{0} \% 0$ for $8^{13} \mathrm{C}$ and $0.45^{0} \%$ for $\delta^{18} \mathrm{O}$.

The mean $\delta^{13} \mathrm{C}$ for nine samples from South Pole, with ages between 500 and 1000 a BP is $-6.69^{\circ} / 00$ and the mean $\delta^{18} \mathrm{O}$ is $-31.4^{0} \% 0$. The $\delta^{13} \mathrm{C}$ results have to be corrected for a contribution by $\mathrm{N}_{2} \mathrm{O}$ which has the same isotopic mass and which was not separated. The corrected $\delta^{13} \mathrm{C}$ value is $-6.34 \pm 0.3^{0} \% 0$, assuming an $\mathrm{N}_{2} \mathrm{O}$ concentration of $286 \mathrm{ppbv}$. This is about $1 \%$ oo higher than the result of $-7.34^{\circ} \% 0$ for modern (1978) atmospheric air reported by Keeling and others (1980).

This result can be compared to model calculations for the $\delta^{13} \mathrm{C}$ change (Siegenthaler and others 1978). A change of $1 \%$ is, according to these calculations, compatible with a relatively wide range of pre-industrial $\mathrm{CO}_{2}$ concentrations and confirms that the observed $\mathrm{CO}_{2}$ increase is due to an input of $\mathrm{CO}_{2}$ from burning of fossil fuel and from the biomass. $\delta^{28} \mathrm{O}$ of atmospheric $\mathrm{CO}_{2}$ is about $0 \%$. The negative values of our samples are probably caused by oxygen exchange between $\mathrm{CO}_{2}$ and water, either in the ice or during the extraction. The uncorrected mean $5^{13} \mathrm{C}$ for three 50 ka BP $\mathrm{CO}_{2}$ samples from an ice core from Byrd station is $-7.58 \%$, which is about $1 \%$ more negative than the value for the South Pole samples. Based on model calculations one would not expect more negative $\delta^{13} \mathrm{C}$ during times of lowered atmospheric $\mathrm{CO}_{2}$ concentration. 
The result from the Byrd samples is, however, much less reliable than the one from the South Pole samples due to the less favourable core quality.

\section{4. ${ }^{14} \mathrm{C}$ dating of $\mathrm{CO}_{2}$ extracted from ice samples \\ ${ }^{14} \mathrm{C}$ dating of ice is an important technique as it} supplements dating methods based on counting annual layers and ice-flow calculations. ${ }^{14} \mathrm{C}$ results will be especially useful for comparing climatic events at the end of the last glaciation recorded in ice cores with records of climatic events in peat bogs and other sediments.

The use of an accelerator mass spectrometer (AMS) permits the measurement of ${ }^{14} \mathrm{C}$ concentration on very small samples. Andrée and others (1984) have performed ${ }^{14} \mathrm{C}$ analyses with $\mathrm{AMS}$ on $\mathrm{CO}_{2}$ extracted from ice core samples from Dye 3 . For one ${ }^{24} \mathrm{C}$ sample, 12 subsequent extraction runs with the new dry extraction device are necessary. The air released is collected and $\mathrm{CO}_{2}$ is separated afterwards by condensation of $\mathrm{CO}_{2}$ and pumping off other gases. The conversion of $\mathrm{CO}_{2}$ to an amorphous carbon deposit, needed for the AMS measurement, is performed in a glow discharge. During the conversion of only $0.3 \mathrm{~cm}^{3} \mathrm{CO}_{2}$, contamination with modern $\mathrm{CO}_{2}$ cannot at present be avoided causing relatively large errors. If $\mathrm{CO}_{2}$ samples of the same size without ${ }^{14} \mathrm{C}$ are converted, the measured ${ }^{14} \mathrm{C}$ concentration of the deposit varies between 5 and $20^{\circ} / 00$ of modern carbon. Due to the high and variable background only relatively young ice samples can be dated up to now. In Table II ${ }^{14} \mathrm{C}$ ages of two ice samples from Dye 3 are compared with ages obtained by other methods.

\section{ACKNOWLEDGEMENTS}

The ice cores from Dye 3 were collected during the international Greenland Ice Sheet Program which was funded by the US National Science Foundation, the Danish Commission for Scientific Research in Greenland, the Danish Natural Science Research Council and the Swiss National Science Foundation. Ice-core samples from Camp Century and Byrd station were obtained with the permission of the Department of Polar Programs, US National Science Foundation, from the ice-core storage facility at the State University of New York at Buffalo. Ice cores from South Pole and Siple stations were obtained during the US Antarctic Program and drilling was performed by the Polar Ice Coring Office in Nebraska. Laboratory work was supported by the Swiss National Science Foundation, the US Department of Energy and the University of Bern.

\section{REFERENCES}

Andrée $\mathrm{M}$ and 10 others $1984{ }^{14} \mathrm{C}$ dating of polar ice. Nucelear Instruments and Methods in Physics Research B5: 385-388

Barnola J M Unpublished Étude des variations passées du $\mathrm{CO}_{2}$ atmosphérique à partir de l'analyse de l'air piégé dans la glace. (Thèse de Troisième Cycle, Université de Grenoble, 1984)

Barnola J M, Raynaud D, Neftel A, Oeschger H 1983 Comparison of $\mathrm{CO}_{2}$ measurements by two laboratories on air from bubbles in polar ice. Nature 303(5916): 410-413

Blatter H, Funk M, Ohmura A 1984 Atlas of solar climate. Zürcher Geographische Schriften 10

Coachman L K, Hemmingsen E, Scholander P F 1956 Gas enclosure in a temperate glacier. Tellus 8(4): 415-423

Craig H, Chou C C 1982 Methane: the record in polar ice cores. Geophysical Research Letters 9(11): 1221-1224

Dansgaard W and 6 others 1982 A new Greenland deep ice core. Science 218(4579): 1273-1277

Friedli H, Moor E, Oeschger H, Siegenthaler U, Stauffer B 1984 First ${ }^{13} \mathrm{C}$ results of $\mathrm{CO}_{2}$ extracted from Antarctic ice. Geophysical Research Letters 11(11): 1145-1148

Gundestrup N S, Johnsen S J, Reeh N 1984 ISTUK: a deep ice core drill system. CRREL Special Report 84-34: 7-19

Hamberg A 1855 Studien über Meereis und Gletschereis. Bihang till Kungliga Svenska Vetenskaps-Akademiens Handlingar 21(Afd 2,2): 3-13
Junge C E 1963 Air chemistry and radioactivity. New York and London, Academic Press.

Keeling C D, Bacastow R B, Tans P P 1980 Predicted shift in the ${ }^{13} \mathrm{C} /{ }^{12} \mathrm{C}$ ratio of atmospheric carbon dioxide. Geophysical Research Letters 7(7): 505-508

Klinger J, Ocampo J 1979 Can we mesure the $\mathrm{CO}_{2}$ content of ancient atmospheres by analyzing gas inclusions of polar ice caps? Colloque international. Évolution des atmosphères planétaires et climatologie de la terre, Nice, 16-20 octobre 1978. Toulouse, Centre National d'Études Spatiales: $95-106$

Kramer S D, Chen C H, Allman S L, Hurst G S, Lehmann B E $1984{ }^{81} \mathrm{Kr}$ detection using resonance ionization spectroscopy. Laser techniques in the extreme ultraviolet. New York, American Institute of Physics: 246-252 (American Institute of Physics. Conference Proceedings 119. Subseries on Optical Science and Engineering 5)

Loosli H H 1983 A dating method with ${ }^{39} \mathrm{Ar}$. Earth and Planetary Science Letters 63: 51-62

Miller S L 1969 Clathrate hydrates of air in Antarctic ice. Science 165(3892): 489-490

Moor E, Stauffer B 1984 A new dry extraction system for gases in ice. Journal of Glaciology 30(106): 358

Neftel A, Oeschger H, Schwander J, Stauffer B 1983 Carbon dioxide concentration in bubbles of natural cold ice. Journal of Physical Chemistry 87(21): 4116-4120

Oeschger $\mathrm{H}$, Stauffer B In press Review of the history of the atmospheric $\mathrm{CO}_{2}$ recorded in ice core. Sixth ORNL Life Science Symposium on the Global Carbon Cycle, Knoxville, 1983

Raynaud D, Delmas R 1977 Composition des gaz contenus dans la glace polaire. International Association of Hydrological Sciences Publication 118 (General Assembly of Grenoble 1975 - Isotopes and Impurities in Snow and Ice): $377-381$

Scholander P F, Kanwisher J W, Nutt D C 1956 Gases in icebergs. Science 123(3186): 104-105

Schwander J, Stauffer B 1984 Age difference between polar ice and the air trapped in its bubbles. Nature 311(5981): 45-47

Shoji H, Langway C C Jr 1982 Air hydrate inclusions in fresh ice core. Nature 298(5874): 548-550

Siegenthaler U, Heimann M, Oeschger H 1978 Model responses of the atmospheric $\mathrm{CO}_{2}$ level and ${ }^{13} \mathrm{C} /{ }^{12} \mathrm{C}$ ratio to biogenic $\mathrm{CO}_{2}$ input. In Williams $\mathrm{J}(e d)$ Carbon dioxide, climate and society. Oxford etc, Pergamon Press: 79-87

Stauffer B, Berner W, Oeschger H, Schwander J 1981 Atmospheric $\mathrm{CO}_{2}$ history from ice core studies. Zeitschrift für Gletscherkunde und Glazialgeologie 17(1): 1-15

Stauffer B, Hofer H, Oeschger H, Schwander J, Siegenthaler $\mathrm{U} 1984$ Atmospheric $\mathrm{CO}_{2}$ concentration during the last glaciation. Annals of Glaciology 5: 160-164

Stauffer B, Neftel A, Oeschger H, Schwander J $1985 \mathrm{CO}_{2}$ concentration in air extracted from Greenland ice samples. In Langway $\mathrm{C}$ C $\mathrm{Jr}$, Oeschger $\mathrm{H}$, Dansgaard $\mathrm{W}$ (eds) Greenland ice core; geophysics, geochemistry and the environment. Washington, DC, American Geophysical Union (Geophysical Monograph 33)

Ueda H T, Garfield D E 1969 Core drilling through the Antarctic ice sheet. CRREL Technical Report 231

Zumbrunn R, Neftel A, Oeschger $\mathrm{H} 1982 \mathrm{CO}_{2}$ measurements on $1 \mathrm{~cm}^{3}$ ice samples with an IR laserspectrometer (IRLS) combined with a new dry extraction device. Earth and Planetary Science Letters 60: 318-324 